\title{
Chemistry, biology and medicine of selected tubulin polymerizing agents*
}

\author{
K. C. Nicolaou, † David Hepworth, N. Paul King and M. Ray V. Finlay \\ Department of Chemistry and The Skaggs Institute for Chemical Biology, The Scripps \\ Research Institute, 10550 North Torrey Pines Road, La Jolla, CA 92037 and Department \\ of Chemistry and Biochemistry, University of California San Diego, 9500 Gilman Drive, \\ La Jolla, CA 92093, USA
}

\begin{abstract}
This article summarizes our work over the past five years into the chemistry and biology of tubulin polymerizing agents. These studies commenced with the total synthesis of $\mathrm{Taxol}^{\circledR}$ and have more recently been concerned with several new natural products, the epothilones, the sarcodictyins and eleutherobin, which share taxol's unusual mechanism of action. Highlights of the total syntheses of these natural products are presented together with our endeavors to produce libraries of structural analogs for biological evaluations. This latter aspect has utilized exciting new developments in solid phase and combinatorial chemistry.
\end{abstract}

\section{INTRODUCTION}

Chemotherapy is arguably one of the most successful ways in which cancer can be treated. Taxol is perhaps the most well known of the recently introduced chemotherapeutic agents, exerting its cytotoxic effect by interfering with the subtle interplay between tubulin and microtubules [1,2]. Microtubules, themselves, are dynamic, polymeric structures that are present in the cytoplasm of all eukaryotic cells and play an important role in many cellular activities. They provide pathways for cellular transport processes, are the building blocks used to construct the cytoskeleton of cells and, perhaps most significantly, they play a crucial part in mitosis (cell division). Since the rapid proliferation of diseased cells is the hallmark of cancer, disruption of cell division pathways is clearly an important target for chemotherapy. To understand more fully the role played by microtubules during mitosis, we must first consider their composition and the dynamic nature of their existence.

Microtubules are assembled from two structurally similar protein subunits, namely $\alpha$-and $\beta$-tubulin, which each contain approximately 440 amino acid residues. The construction of microtubules from these smaller fragments involves initial formation of a heterodimeric species containing individual $\alpha$-and $\beta$ units which are connected in a head-to-tail fashion as depicted in Fig. 1 [3]. Controlled polymerization of these dimeric species then occurs in the presence of magnesium and calcium ions, under the aegis of microtubule associated proteins (MAP's), to give a polymeric chain, known as a protofilament. This substructure then provides a nucleation center for the attachment of additional heterodimers resulting in the production of the microtubule itself. The tubular structure, which contains 13 protofilaments connected in a helical arrangement is, however, not static and continual gain and loss of tubulin subunits occurs in a nonsymmetrical manner resulting in growth of the microtubule at one end, deemed the plus-end, and diminution of the other, so-called minus-end (Fig. 1).

The dynamic nature of these mobile tubular structures is exploited in the later stages of mitosis which is outlined in simplified form in Fig. 2. In the earlier stages of the process, genetic information contained within the chromosomes of the parent cell is duplicated to give two identical sets of chromatids. During

*Lecture presented at the 7th International Chemistry Conference in Africa \& 34th Convention of the South African Chemical Institute, Durban Africa, 6-10 July 1998, pp. 919-1024.

$\dagger$ Corresponding author. 


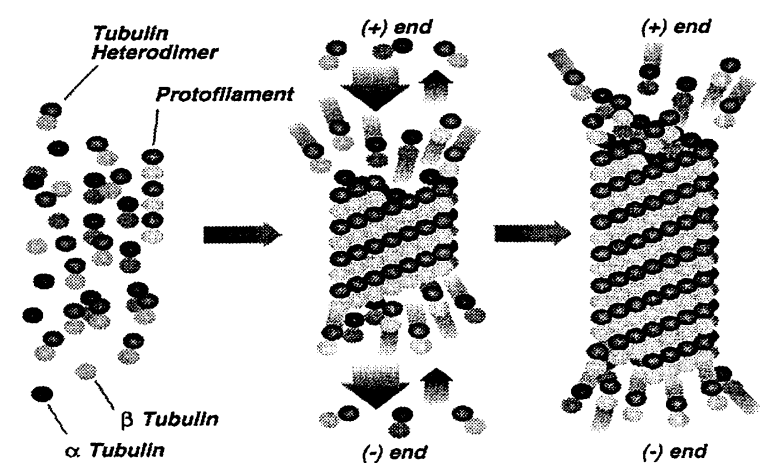

Fig. 1 Controlled polymerization of tubulin to microtubules.

the metaphase stage of mitosis, substantial breakdown of the cytoskeleton of the cell occurs releasing a high concentration of free tubulin into the cytoplasm. Reassembly of the tubulin then occurs to give a structure known as the mitotic spindle. The chromatids attach to this framework and become aligned at the equator of the cell. Subsequently, during transition to anaphase, the mitotic spindle pulls the chromatids apart, thus separating the genetic information. Further processes lead eventually to the production of two identical daughter cells.

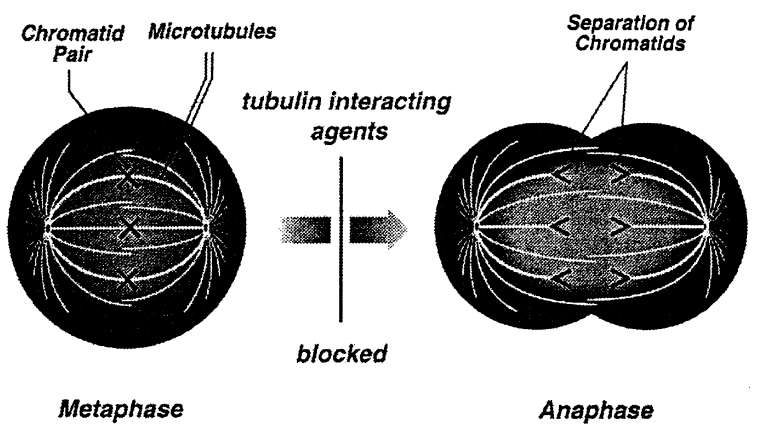

Fig. 2 Simplified representation of the latter stages of mitosis.

There are a number of compounds which interact with tubulin and disrupt the cell division process. The majority of these act primarily by destabilizing the structure of microtubules. However, taxol (1, Fig. 3) exhibits a mode of action which involves promoting the formation of microtubules and stabilizing the resulting microtubule structure [4]. Although this may, in theory, disrupt any cell process involving tubulin, it is the substantial reorganization of microtubules that occurs on formation of the mitotic spindle which permits molecules with this property to act most destructively on rapidly dividing cells. At this juncture, it is worth noting that the majority of conventional chemotherapeutic agents act by interfering with DNA replication during mitosis. This results in the production of daughter cells with damaged DNA which may sufficiently disrupt subsequent intracellular processes to cause cell death or, alternatively, may lead to the proliferation of diseased cells. Clearly, the latter of these outcomes is highly undesirable. In the presence of taxol, incorrect assembly of the mitotic spindle makes the cell unable to pass a 'checkpoint' in the cell cycle and this triggers the cell to 'commit suicide', a process known as apoptosis. Thus, all taxol-affected cells will die and it is this feature which sets taxol apart from other chemotherapeutic treatments.

Due to its poor water solubility, taxol was initially ignored as a potential drug candidate, but following the discovery of its unique mechanism of cytotoxicity described above, this situation altered. Taxol, and its closely related analog Taxotere ${ }^{\mathrm{TM}}$, are now multimillion dollar drugs of great clinical importance. Despite this success, however, taxol is by no means a perfect drug. Resistant cell lines have emerged which are unaffected by taxol and its low solubility requires it to be formulated with Cremaphor, a 


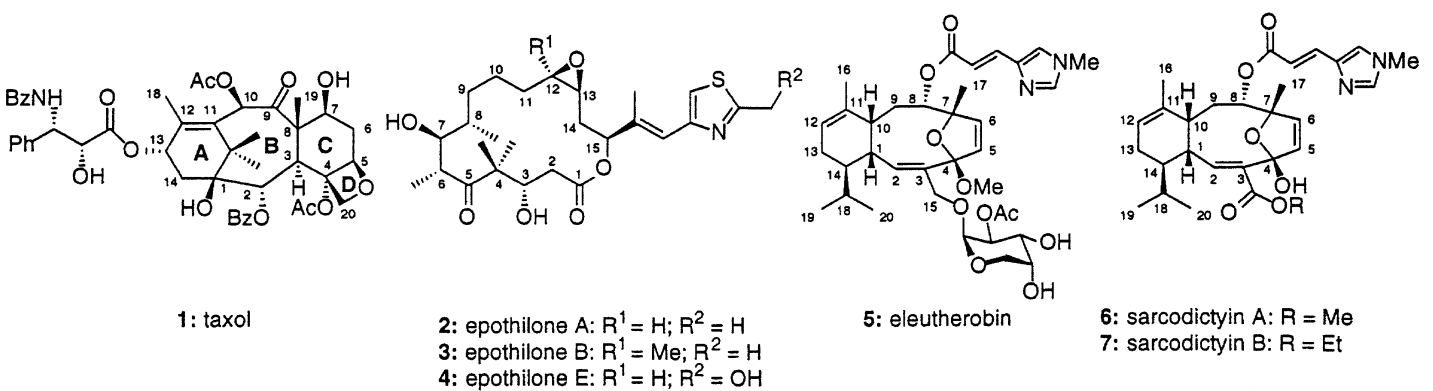

Fig. 3 Structures and numbering of selected tubulin polymerizing agents.

substance possessing unpleasant side-effects which compound those caused by the drug itself. Thus, the search for more potent and selective drugs with improved pharmacological properties has continued unabated. Despite intense efforts, only recently have alternative compounds exhibiting a taxol-like mode of action been discovered. The extended family of microtubule stabilizing compounds now includes the epothilones (2-4) [5], eleutherobin (5) [6], sarcodictyins (6-7) [7,8] (Fig. 3) and discodermolide [9]. The recent discovery of these tubulin stabilizing agents has created much excitement in chemistry, biology and medicine and the remainder of this article will consider several of these exciting molecules in more detail.

\section{TAXOL}

The efficacy of taxol and its extraordinary mechanism of action alone would have been enough to motivate organic chemists to investigate the possibility of its total synthesis. However, the extremely challenging molecular architecture of taxol provided an ideal stage for many of the leading practitioners of natural products synthesis to perform their art.

Taxol's structure presents numerous and formidable synthetic challenges. Simply assembling unfunctionalized models of the eight-membered B-ring [10] proved notoriously difficult due to transannular interactions which are further exacerbated by the gem-dimethyl substituted bridge with the A-ring. In taxol itself, these difficulties are compounded by the complexity of the densely packed oxygenated functionality throughout the molecule and the many stereogenic centers. In addition, there are three quaternary stereogenic carbon centers and a potentially labile oxetane D-ring to be constructed. Despite these awesome structural features, the total synthesis of taxol has been achieved, so far by five groups [11-16]. The synthetic approach that we adopted is outlined in Fig. 4.

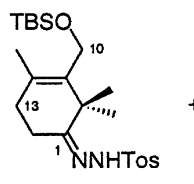

8

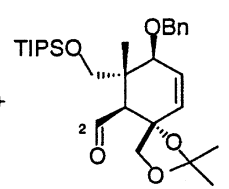

9
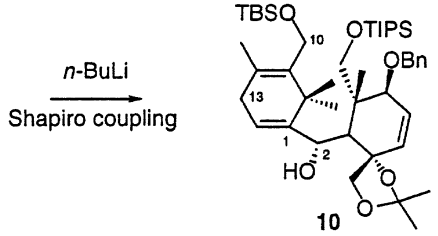
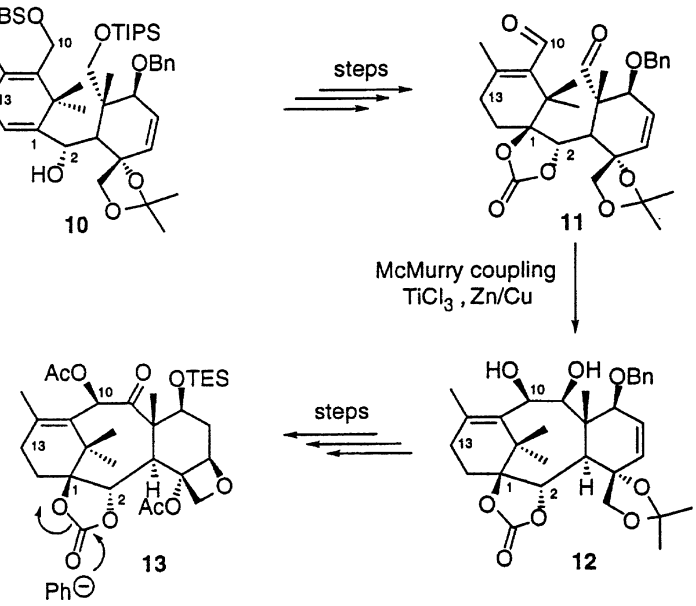

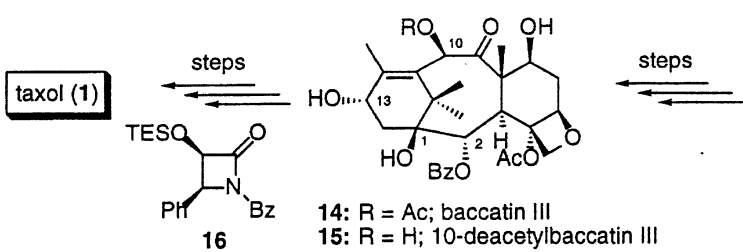

Fig. 4 Key intermediates and key steps used in the total synthesis of taxol (1) by this group $[11,12]$. 
Since introduction of the $\beta$-amino acid side-chain at C13 had been studied previously [10], the synthetic problem was reduced to the assembly of the core structure, baccatin III (14). We opted for a highly convergent strategy utilizing fragments $\mathbf{8}$ and $\mathbf{9}$, both of which were prepared using Diels-Alder reactions. Union of these two fragments was achieved with high efficiency and selectivity through a Shapiro coupling to give $\mathbf{1 0}$ as a single isomer. Following a number of functional group manipulations, including oxygenation at $\mathrm{C} 1$ and installation of the cyclic carbonate, we arrived at key dialdehyde $\mathbf{1 1}$ in preparation for closure of the B-ring. Although the McMurry coupling of 11 proved to be the bottle-neck which limited the supply of material for the closing steps of the synthesis, our decision to adopt this rather bold convergent strategy was rewarded with sufficient material to achieve the final goal. Of the remaining steps in the synthesis, perhaps the most notable are introduction of the oxetane D-ring, which in the end turned out to be far more robust than originally anticipated, and regioselective opening of the cyclic carbonate group of $\mathbf{1 3}$ with phenyllithium to release the $\mathrm{C} 1$ hydroxy group and simultaneously install the $\mathrm{C} 2$ benzoate ester [17]. This transformation is truly remarkable given the number of electrophilic groups which might be expected to undergo reactions with the highly nucleophilic organometallic reagent (two acetate esters, a ketone and the oxetane). We were able to utilize this reaction to synthesize a number of $\mathrm{C} 2$ taxol analogs (e.g. 17, Fig. 5), by opening the carbonate group of $\mathbf{1 3}$ with a variety of organolithium reagents [18]. Some of these analogs exhibited impressive levels of cytotoxicity and tubulin polymerization activity [19].

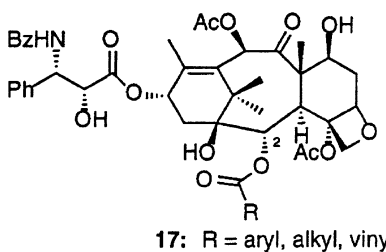

17: $R=$ aryl, alkyl, vinyl

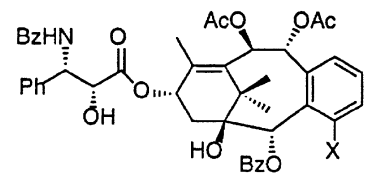

18: $X=H, O M e, O B n$

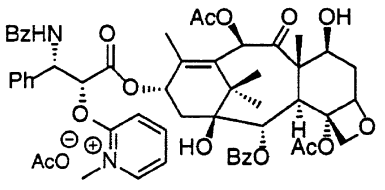

19

Fig. 5 Selected taxol analogs prepared in these laboratories.

Following attack of $\mathbf{1 3}$ by phenyllithium, C13 oxidation and subsequent stereoselective reduction afforded baccatin III (14). The remaining synthetic steps through to taxol had been established in our group using retrosynthetic and degradation studies of natural 10-deacetylbaccatin III (15) [17], and were performed as described previously to complete our conquest of taxol $[11,20]$.

In addition to the $\mathrm{C} 2$ modified analogs already mentioned, we also prepared such analogs as $\mathbf{1 8}$ in which the C-ring was replaced with a aromatic moiety [21]. Unfortunately, most of these derivatives exhibited significantly reduced cytotoxicity and tubulin polymerization activity as compared to the natural product. Perhaps the most notable of the analogs we prepared was the pyridinium derivative 19 [22]. This molecule, a prodrug of taxol [23], exhibits far greater water solubility than the natural product which should allow for easier formulation, whilst retaining high activity.

\section{EPOTHILONES}

Although the biological profile of taxol is highly impressive, the more recently discovered epothilones [5] manifest significantly improved levels of tubulin polymerization and cytotoxic activity [24]. The disclosure of the absolute stereochemistry [25] of both epothilone A (2) and B (3) and the revelation that their mode of action mirrored that of taxol, prompted a flurry of synthetic activity [2], with publications by both ourselves and others beginning to appear in 1996 and 1997 [2,26-29]. To provide maximum flexibility in our endeavors, we adopted several synthetic strategies as outlined in Figs 6-8. Our initial approach utilized ring-closing olefin metathesis (RCM) to form the $\mathrm{C} 12,13$ double bond and simultaneously establish the macrocyclic skeleton of epothilone A (Fig. 6) [28a-c].

The RCM substrate, triene $\mathbf{2 4}$, was assembled rapidly from three key fragments 20-22 in a highly convergent manner as shown in Fig. 6. The chirality and functionality of the keto-acid fragment $\mathbf{2 0}$ and the thiazole fragment $\mathbf{2 1}$ were installed by asymmetric allylboration, whereas aldehyde fragment $\mathbf{2 2}$ $\left(\mathrm{R}^{\prime}=\mathrm{H}\right)$ was prepared using an asymmetric alkylation protocol. Union of fragments $\mathbf{2 0}$ and $22\left(\mathrm{R}^{\prime}=\mathrm{H}\right)$ was achieved using a high yielding syn-aldol reaction and an ensuing esterification reaction with alcohol 
<smiles>[R]C=CCCC[C@H](C=O)CC[C@H](O)/C(C)=C/c1csc(C)n1</smiles>

20

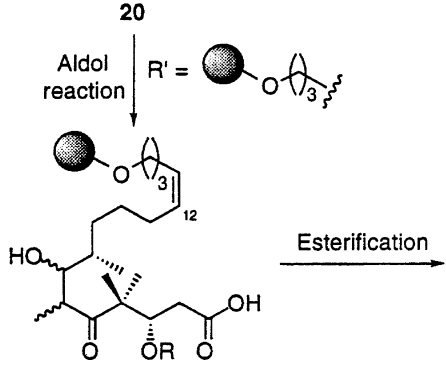

26

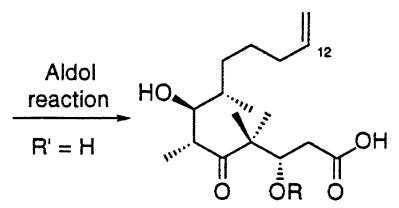

23

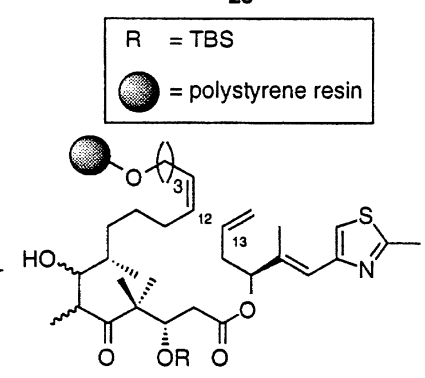

27

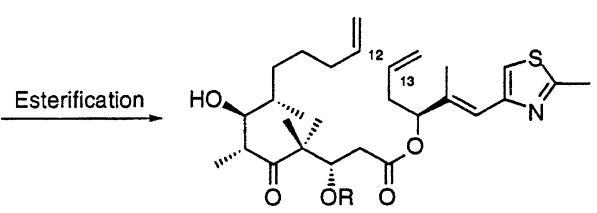

24
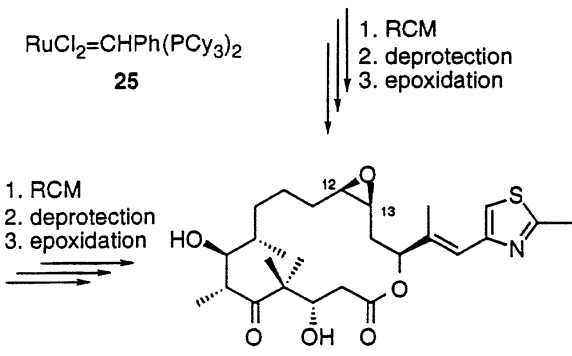

epothilone A (2)

Fig. 6 Solution and solid phase synthesis of epothilone (2) via the ring-closing metathesis (RCM) approach.

21 furnished the desired triene $\mathbf{2 4}$ via acid 23. In a remarkable demonstration of the tolerance of the RCM initiator 25 [30] for a wide variety of sensitive functionality, the olefin metathesis proceeded cleanly and in good yield, delivering a mixture of geometric isomers.

Deprotection and epoxidation of the desired C12 Z-isomer, furnished epothilone A (2) in good yield. A solid phase version of this strategy was also demonstrated using resin-bound aldehyde $\mathbf{2 2}\left(\mathrm{R}^{\prime}=\right.$ polymeric linker, Fig. 6) [28b]. This method, which permits simultaneous formation of the macrocycle and release from the resin, allowed the generation of a large library of epothilone analogs for biological screening [31].

The metathesis approach has also been applied to the synthesis of epothilone E (4, Fig. 7) [32]. Triene $\mathbf{2 8}$, which was prepared in a similar way to that described for $\mathbf{2 4}$, underwent RCM to afford macrocycle $\mathbf{2 9}$ (and its $E$-isomer). Subsequent palladium-catalyzed Stille coupling with stannane $\mathbf{3 0}$ was followed by epoxidation to complete the total synthesis.

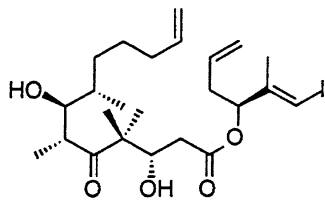

28

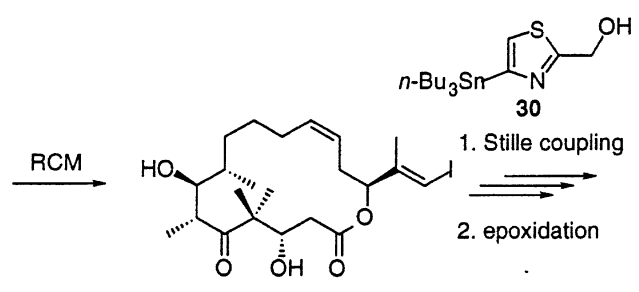

29

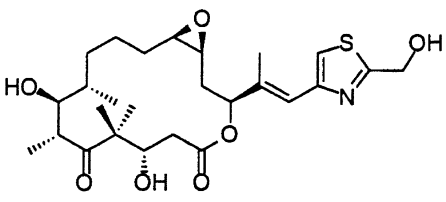

epothilone $E(4)$

Fig. 7 Synthesis of epothilone E (4) via the ring-closing metathesis (RCM)-Stille coupling approach.

Our second approach to the epothilones employed a macrolactonization-based strategy [28b,28d,33] to prepare the epothilone core and utilized two of the fragments used previously in the metathesis approach. Firstly, fragment 21 (Fig. 6) was extended, using Wittig chemistry to introduce the C12 unsaturation, giving aldehyde 31 (Fig. 8). An ensuing aldol reaction with keto-acid 20 established the epothilone A framework 33. In a similar fashion, the epothilone B fragment $\mathbf{3 4}$ was prepared from aldehyde $\mathbf{3 2}$. Further elaboration of these fragments, including an efficient macrolactonization under Yamaguchi conditions, delivered the natural products ( $\mathbf{2}$ and $\mathbf{3}$ ).

Having synthesized the naturally occurring epothilones A, B and E, we turned our attention to the production of a library of analogs for biological screening purposes. The synthetic routes developed during the synthesis of the natural products, and in particular the solid phase strategies, proved readily 

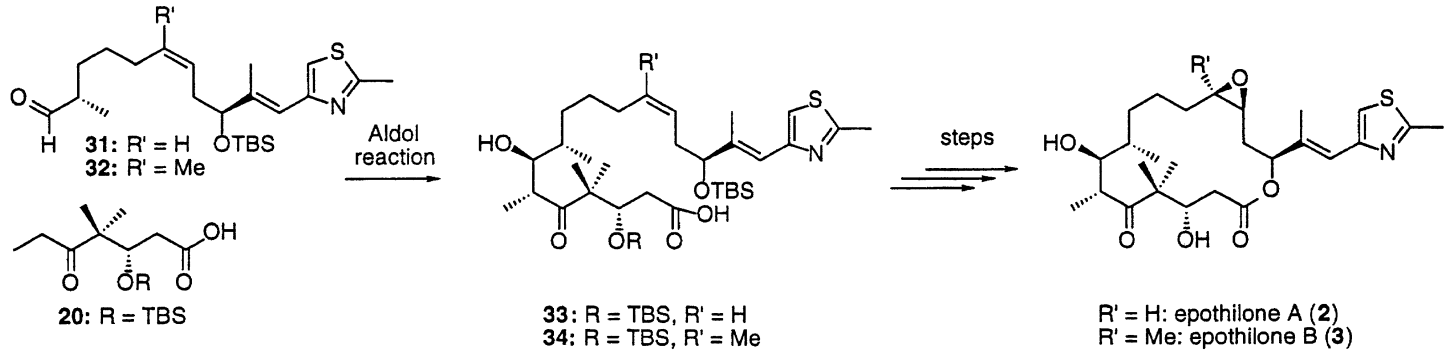

Fig. 8 Synthesis of epothilone A (2) and epothilone B (3) via the macrolactonization approach.

adaptable to analog generation and a large number of modifications at key structural positions were made $[2,31,34]$. Many of these 'designed epothilones' display considerable biological activity, some rivaling that of the natural substances.

\section{ELEUTHEROBIN AND SARCODICTYINS A AND B}

Recently, the focus of our studies on tubulin binding agents has shifted towards three marine-derived diterpenoids, namely, eleutherobin (5) and sarcodictyins A (6) and B (7) (Fig. 3) [6-7]. In 1997, Fenical and co-workers reported that the mode of action of eleutherobin was similar to that of taxol and this prompted us to engage in synthetic and chemical biology endeavors around these target molecules. In contrast to the taxol and epothilone programs, the scarcity of 5-7 meant that their total synthesis was vital for further biological investigations and to ensure that their chemotherapeutic potential could be achieved.

The three natural products possess the same synthetically challenging tricyclic skeleton and differ only by the substituents present at $\mathrm{C} 3$ and $\mathrm{C} 4$ (Fig. 3). The syntheses of all three compounds followed that which is outlined for eleutherobin in Fig. 9 [35-36].

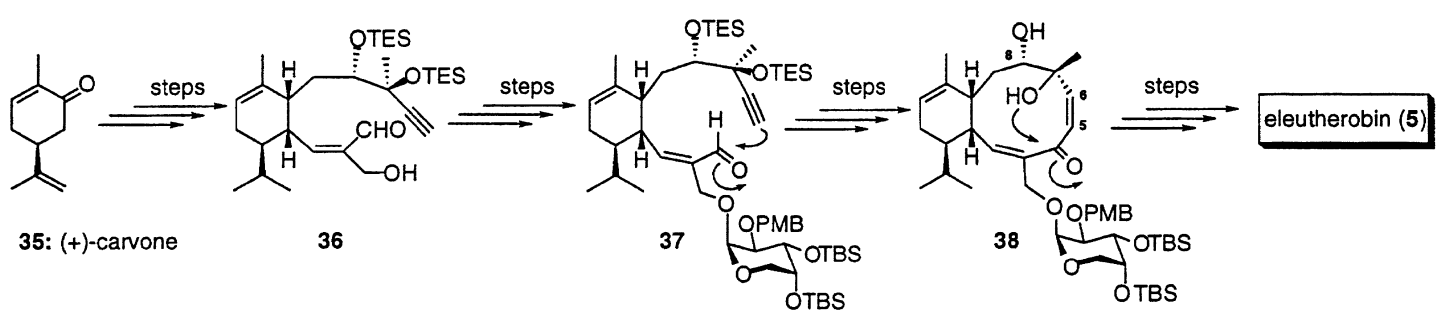

Fig. 9 Key intermediates and important steps used in the total synthesis of eleutherobin (5).

Thus, naturally occurring (+)-carvone (35) was elaborated into intermediate $\mathbf{3 6}$ possessing two 'arms' which, following glycosidation to give $\mathbf{3 7}$, were joined by an intramolecular acetylide-aldehyde condensation to form the required 10-membered ring. Partial hydrogenation of the acetylenic bond afforded hydroxy-enone $\mathbf{3 8}$ which spontaneously collapsed to the desired tricyclic core structure. Further processing and introduction of the $N\left(6^{\prime}\right)$-methylurocanic acid side chain at $\mathrm{C} 8$ completed the synthesis.

For the synthesis of sarcodictyins and eleutherobin analogs [37] we focused primarily on a solid phase combinatorial approach. This strategy allowed two elements of diversity to be introduced onto the resinbound sarcodictyin core 39 to give intermediate $\mathbf{4 0}$ (Fig. 10) [38]. Introduction of a third element of diversity occurred with concomitant cleavage from the resin to afford analog $\mathbf{4 1}$. Chemical biology studies in this area are continuing.

\section{CONCLUSIONS}

The identification of the tubulin polymerization - microtubule stabilization mode of action of taxol [4] and its subsequent emergence as a major clinical anticancer treatment of outstanding therapeutic and commercial success has motivated further research into the chemistry and biology of tubulin 


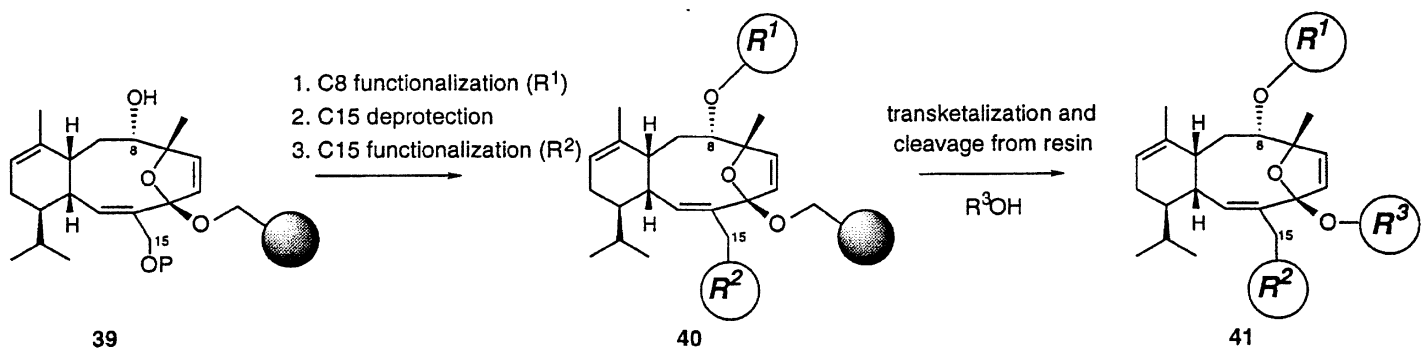

Fig. 10 Synthetic strategy used to introduce three elements of diversity around the sarcodictyin molecular scaffold and generate a sarcodictyin library.

polymerization agents. In addition to the natural products themselves, our enterprise in this area has yielded an extensive number of analogs, particularly in the case of the epothilones and sarcodictyins where combinatorial approaches have been applied. The wealth of structure activity information obtained from the study of these potential anticancer agents has been augmented by a bounty of chemical knowledge. Given the promising results so far obtained in this area, further developments are eagerly anticipated.

\section{ACKNOWLEDGEMENTS}

This work was financially supported by The Skaggs Institute for Chemical Biology, the National Institutes of Health USA, fellowships from the George E. Hewitt Foundation (N.P.K.), and the Fulbright Commission (M.R.V.F.), and grants from Novartis, CaPCURE, Pfizer, Merck, DuPont-Merck, Hoffmann LaRoche and Schering-Plough. We also greatly appreciate the assistance of Nicolas Winssinger in the preparation of Figs 1 and 2.

\section{REFERENCES}

1 J. S. Hyams, C. W. Lloyd, eds. Microtubules. Wiley-Liss Inc., New York (1994).

2 K. C. Nicolaou, F. Roschangar, D. Vourloumis. Angew. Chem. Int. Ed 37, 2014-2045 (1998).

3 E. Nogales, S. G. Wolf, K. H. Downing. Structure of the $\alpha, \beta$-tubulin dimer. Nature (London) 393, 191 (1998).

4 P. B. Schiff, J. Fant, S. B. Horwitz. Nature (London) 277, 665-667 (1979).

5 K. Gerth, N. Bedorf, G. Höfle, H. Irschik, H. Reichenbach. J. Antibiot. 49, 560-563 (1996).

6 (a) T. Lindel, P. R. Jensen, W. Fenical, B. H. Long, A. M. Casazza, J. Carboni, C. R. Fairchild. J. Am. Chem. Soc. 119, 8744-8745 (1997). (b) B. H. Long, J. M. Carboni, A. J. Wasserman, L. A. Cornell, A. M. Casazza, P. R. Jensen, T. Lindel, W. Fenical, C. R. Fairchild. Cancer Res. 58, 1111-1115 (1998).

7 (a) M. D’Ambrosio, A. Guerriero, F. Pietra. Helv. Chim. Acta 70, 2019-2027 (1987). (b) M. D'Ambrosio, A. Guerriero, F. Pietra. Helv. Chim. Acta 71, 964-976 (1988). (c) M. Ciomei, C. Albanese, W. Pastori, M. Grandi, F. Pietra, M. D’Ambrosio, A. Guerriero, C. Battistini. Proc. Amer. Ass. Canc. Res. 38(5), Abstract 30 (1997).

8 For the isolation of related, 'eleuthosides' see: S. Ketzinel, A. Rudi, M. Schleyer, Y. Benayahu, Y. Kashman. J. Nat. Prod. 59, 873-875 (1996).

9 Isolation (a) S. B. Gunasekera, M. Gunasekera, R. E. Longley. J. Org. Chem. 56, 1346 (1991). Synthesis: (b) D. T. Hung, J. B. Nerenberg, S. L. Schreiber. J. Am. Chem. Soc. 118, $11054-11080$ (1996). (c) P. L. Evans, J. M. C. Golec, R. L. Gillespie, Tetrahedron 34, 8163-8166 (1993). (d) A. B. Smith III, Y. Qiu, D. R. Jones, K. Kobayashi. J. Am. Chem. Soc. 117, $12011-12012$ (1995); (e) S. S. Harried, G. Yang, M. A. Strawn, D. C. Myles. J. Org. Chem. 62, 6098-6099 (1997).

10 K. C. Nicolaou, W.-M. Dai, R. K. Guy. Angew. Chem. Int. Ed. Engl. 33, 15-44 (1994).

11 K. C. Nicolaou, Z. Yang, J. J. Liu, H. Ueno, P. G. Nantermet, R. K. Guy, C. F. Claiborne, J. Renaud, E. A. Couladouros, K. Paulvannan, E. J. Sorensen. Nature (London) 367, 630-634 (1994).

12 For full papers on this work see (a) K. C. Nicolaou, J.-J. Liu, Z. Yang, H. Ueno, R. K. Guy, E. A. Couladoros, E. J. Sorensen. J. Am. Chem. Soc. 117, 624-633 (1995). (b) K. C. Nicolaou, J.-J. Liu, Z. Yang, H. Ueno, E. J. Sorensen, C. F. Claiborne, R. K. Guy, C.-K. Hwang, M. Nakada, P. G. Nantermet. J. Am. Chem. Soc. 117, 
634-644 (1995). (c) K. C. Nicolaou, Z. Yang, J.-J. Liu, P. G. Nantermet, C. F. Claiborne, J. Renaud, R. K. Guy, K. Shibayama. J. Am. Chem. Soc. 117, 645-652 (1995). (d) K. C. Nicolaou, H. Ueno, J.-J. Liu, P. G. Nantermet, Z. Yang, J. Renaud, K. Paulvannan, R. Chadha. J. Am. Chem. Soc. 117, 653-659 (1995).

13 (a) R. A. Holton, C. Somoza, H.-B. Kim, F. Liang, R. J. Biediger, P. D. Boatman, M. Shindo, C. C. Smith, S. Kim, H. Nadizadeh, Y. Suzuki, C. Tao, P. Vu, S. Tang, P. Zhang, K. K. Murthi, L. N. Gentile, L. H. Liu. J. Am. Chem. Soc. 116, 1597-1598 (1994). (b) R. A. Holton, H.-B. Kim, C. Somoza, F. Liang, R. J. Biediger, P. D. Boatman, M. Shindo, C. C. Smith, S. Kim, H. Nadizadeh, Y. Suzuki, C. Tao, P. Vu, S. Tang, K. K. Murthi, L. N. Gentile, J. H. Liu. J. Am. Chem. Soc. 116, 1599-1600 (1994).

14 (a) J. J. Masters, J. T. Link, L. B. Snyder, W. B. Young, S. J. Danishefsky. Angew. Chem. Int. Ed. Engl. 34, 1723-1726 (1995). (b) S. J. Danishefsky, J. J. Masters, W. B. Young, J. T. Link, L. B. Snyder, T. V. Magee, D. K. Jung, R. C. A. Isaacs, W. G. Bornmann, C. A. Alaimo, C. A. Coburn, M. J. Di Grandi. J. Am. Chem. Soc. 118, 2843-1859 (1996).

15 (a) P. A. Wender, N. F. Badham, S. P. Conway, P. E. Floreancig, T. E. Glass, C. Gränicher, J. B. Houze, J. Jänichen, D. Lee, D. G. Marquess, P. L. McGrane, W. Meng, T. P. Mucciaro, M. Mühlebach, M. G. Natchus, H. Paulsen, D. B. Rawlins, J. Satofsky, A. J. Shuker, J. C. Sutton, R. E. Taylor, K. Tomooka. J. Am. Chem. Soc. 119, 2755-2756 (1997). (b) P. A. Wender, N. F. Badham, S. P. Conway, P. E. Floreancig, T. E. Glass, J. B. Houze, N. E. Krauss, D. Lee, D. G. Marquess, P. L. McGrane, W. Meng, M. G. Natchus, A. J. Shuker, J. C. Sutton, R. E. Taylor. J. Am. Chem. Soc. 119, 2757-2758 (1997).

16 T. Mukaiyama, I. Shima, H. Iwadare, H. Sakoh, Y. Tani, M. Hasegawa, K. Saitoh. Proc. Japan. Acad. 73B, 95 (1997).

17 K. C. Nicolaou, P. G. Nantermet, H. Ueno, R. K. Guy. J. Chem. Soc., Chem. Commun. 295-296 (1994).

18 K. C. Nicolaou, E. A. Couladouros, P. G. Nantermet, J. Renaud, R. K. Guy, W. Wrasidlo. Angew. Chem. Int. Ed. Engl. 33, 1581-1583 (1994).

19 K. C. Nicolaou, J. Renaud, P. G. Nantermet, E. A. Couladouros, R. K. Guy, W. Wrasidlo. J. Am. Chem. Soc. 117, 2409-2420 (1995).

20 For an 'inside story' of the Taxol synthesis see: K. C. Nicolaou, R. K. Guy. Angew. Chem. Int. Ed. Engl. 34, 2047-2059 (1995).

21 (a) K. C. Nicolaou, C. F. Claiborne, P. G. Nantermet, E. A. Couladouros, E. J. Sorensen. J. Am. Chem. Soc. 116, 1591-1592 (1994). (b) K. C. Nicolaou, C. F. Claiborne, K. Paulvannan, M. H. D. Postema, R. K. Guy. Chem. Eur. J. 3, 399-409 (1997).

22 (a) K. C. Nicolaou, R. K. Guy, E. N. Pitsinos, W. Wrasidlo. Angew. Chem. Int. Ed. Engl. 33, 1583-1587 (1994). (b) L. G. Paloma, R. K. Guy, W. Wrasidlo, K. C. Nicolaou. Chem. Biol. 1, 107-112 (1994).

23 For other work on protaxols see: K. C. Nicolaou, C. Riemer, M. A. Kerr, D. Rideout, W. Wrasidlo. Nature (London) 364, 464-466 (1993).

24 D. M. Bollag, P. A. McQueney, J. Zhu, O. Hensens, L. Koupal, J. Liesch, M. Goetz, E. Lazarides, C. M. Woods. Cancer Res. 55, 2325-2333 (1995).

25 G. Höfle, N. Bedorf, H. Steinmetz, D. Schomburg, K. Gerth, H. Reichenbach. Angew. Chem. Int. Ed. Engl. 35, 1567-1569 (1996).

26 For a brief overview of work in this area see: M. R. V. Finlay. Chem. Ind. (London) 991-996 (1997).

27 (a) A. Balog, D. Meng, T. Kamenecka, P. Bertinato, E. J. Sorensen, S. J. Danishefsky. Angew. Chem. Int. Ed. Engl. 35, 2801-2803 (1996). (b) D.-S. Su, D. Meng, P. Bertinato, A. Balog, E. J. Sorensen, S. J. Danishefsky, Y.-H. Zheng, T.-C. Chou, L. He, S. B. Horwitz. Angew. Chem. Int. Ed. Engl. 36, 757-759 (1997). (c) D. Meng, P. Bertinato, A. Balog, D.-S. Su, T. Kamenecka, E. J. Sorensen, S. J. Danishefsky. J. Am. Chem. Soc. 119, 10073-10092 (1997).

28 (a) Z. Yang, Y. He, D. Vourloumis, H. Vallberg, K. C. Nicolaou. Angew. Chem. Int. Ed. Engl. 36, 166-168 (1997). (b) K. C. Nicolaou, N. Winssinger, J. A. Pastor, S. Ninkovic, F. Sarabia, Y. He, D. Vourloumis, Z. Yang, T. Li, P. Giannakakou, E. Hamel. Nature (London) 387, 268-272 (1997). (c) K. C. Nicolaou, Y. He, D. Vourloumis, H. Vallberg, F. Roschangar, F. Sarabia, S. Ninkovic, Z. Yang, J. I. Trujillo. J. Am. Chem. Soc. 119, 7960-7973 (1997). (d) K. C. Nicolaou, S. Ninkovic, F. Sarabia, D. Vourloumis, Y. He, H. Vallberg, M. R. V. Finlay, Z. Yang. J. Am. Chem. Soc. 119, 7974-7991 (1997).

29 D. Schinzer, A. Limberg, A. Bauer, O. M. Böhm, M. Cordes. Angew. Chem. Int. Ed. Engl. 36, 523-524 (1997).

30 (a) S. T. Nguyen, L. K. Johnson, R. H. Grubbs. J. Am. Chem. Soc. 114, 3974-3975 (1992). (b) P. Schwab, M. B. France, J. W. Ziller, R. H. Grubbs. Angew. Chem. Int. Ed. Engl. 34, 2039-2041 (1995). 
31 K. C. Nicolaou, D. Vourloumis, T. Li, J. Pastor, N. Winssinger, Y. He, S. Ninkovic, F. Sarabia, H. Vallberg, F. Roschangar, N. P. King, M. R. V. Finlay, P. Giannakakou, P. Verdier-Pinard, E. Hamel. Angew. Chem. Int. Ed. Engl. 36, 2097-2103 (1997).

32 (a) K. C. Nicolaou, Y. He, F. Roschangar, N. P. King, D. Vourloumis, T. Li. Angew. Chem. Int. Ed. 37, 84-87 (1998). (b) K. C. Nicolaou, N. P. King, M. R. V. Finlay, Y. He, F. Roschangar, D. Vourloumis, H. Vallberg, F. Sarabia, S. Ninkovic, D. Hepworth. Bioorg. Med. Chem. 7, 665-697 (1999).

33 K. C. Nicolaou, F. Sarabia, S. Ninkovic, Z. Yang. Angew. Chem. Int. Ed. Engl. 36, 525-527 (1997).

34 For full details of our epothilone analogs program see: (a) K. C. Nicolaou, H. Vallberg, N. P. King, F. Roschangar, Y. He, D. Vourloumis, C. G. Nicolaou. Chem. Eur. J. 3, 1957-1970 (1997). (b) K. C. Nicolaou, F. Sarabia, M. R. V. Finlay, S. Ninkovic, N. P. King, D. Vourloumis, Y. He. Chem. Eur. J. 3, 1971-1986 (1997). (c) K. C. Nicolaou, S. Ninkovic, M. R. V. Finlay, F. Sarabia, T. Li. Chem. Commun. 2343-2344 (1997). (d) K. C. Nicoloau, F. Sarabia, S. Ninkovic, M. R. V. Finlay, C. N. C. Boddy. Angew. Chem. Int. Ed. 37, 81-84 (1998). (e) K. C. Nicolaou, M. R. V. Finlay, S. Ninkovic, F. Sarabia. Tetrahedron 54, 7127-7166 (1998). (f) K. C. Nicolaou, M. R. V. Finlay, S. Ninkovic, N. P. King, Y. He, T. Li, F. Sarabia, D. Vourloumis. Chem. Biol. 5, 365-327 (1998).

35 (a) K. C. Nicolaou, J.-Y. Xu, S. Kim, T. Ohshima, S. Hosokawa, J. Pfefferkorn. J. Am. Chem. Soc. 119, 11353-11354 (1997). (b) K. C. Nicoloau, F. L. van Delft, T. Ohshima, D. Vourloumis, J.-Y. Xu, S. Hosokawa, J. Pfefferkorn, S. Kim, T. Li. Angew. Chem. Int. Ed. Engl. 36, 2520-2524 (1997). (c) K. C. Nicolaou, J.-Y. Xu, S. Kim, J. Pfefferkorn, T. Ohshima, D. Vourloumis, S. Hosokawa. J. Am. Chem. Soc. 120, 8661-8673 (1998). (d) K. C. Nicoloau, T. Ohshima, S. Hosokawa, F. L. van Delft, D. Vourloumis, J.-Y. Xu, J. Pfefferkorn, S. Kim. J. Am. Chem. Soc. 120, 8674-8680 (1998).

36 For an alternative synthesis of eleutherobin see: X.-T. Chen, B. Zhou, S. K. Bhattarya, C. E. Gutteridge, T. R. R. Pettus, S. J. Danishefsky. Angew. Chem. Int. Ed. 37, 789-792 (1998).

37 For solution phase analog syntheses see: K. C. Nicolaou, S. Kim, J. Pfefferkorn, J.-Y. Xu, T. Ohshima, S. Hosokawa, N. Winssinger, D. Vourloumis, T. Li. Angew. Chem. Int. Ed. 37, 1418-1421 (1998).

K. C. Nicolaou, et al. unpublished results. 